\title{
A framework for modelling the complexities of food and water security under globalisation
}

\author{
Brian J. Dermody ${ }^{1,2,3}$, Murugesu Sivapalan ${ }^{4}$, Elke Stehfest ${ }^{5}$, Detlef P. van Vuuren ${ }^{1,5}$, Martin J. Wassen ${ }^{1}$, \\ Marc F. P. Bierkens ${ }^{6}$, and Stefan C. Dekker ${ }^{1,7}$ \\ ${ }^{1}$ Copernicus Institute of Sustainable Development, Faculty of Geosciences, Utrecht University, the Netherlands \\ ${ }^{2}$ Centre for Complex Systems Studies, Utrecht University, the Netherlands \\ ${ }^{3}$ Department of Science, University College Utrecht, the Netherlands \\ ${ }^{4}$ Department of Civil and Environmental Engineering, Department of Geography and Geographic Information \\ Science, University of Illinois at Urbana-Champaign, Urbana, IL 61801, USA \\ ${ }^{5}$ PBL Netherlands Environmental Assessment Agency, The Hague, the Netherlands \\ ${ }^{6}$ Department of Physical Geography, Faculty of Geosciences, Utrecht University, the Netherlands \\ ${ }^{7}$ Faculty of Management, Science and Technology, Department of Science, Open University, \\ Heerlen, the Netherlands \\ Correspondence: Brian J. Dermody (b.dermody@uu.nl)
}

Received: 31 March 2017 - Discussion started: 18 April 2017

Revised: 19 November 2017 - Accepted: 16 December 2017 - Published: 31 January 2018

\begin{abstract}
We present a new framework for modelling the complexities of food and water security under globalisation. The framework sets out a method to capture regional and sectoral interdependencies and cross-scale feedbacks within the global food system that contribute to emergent water use patterns. The framework integrates aspects of existing models and approaches in the fields of hydrology and integrated assessment modelling. The core of the framework is a multi-agent network of city agents connected by infrastructural trade networks. Agents receive socio-economic and environmental constraint information from integrated assessment models and hydrological models respectively and simulate complex, socio-environmental dynamics that operate within those constraints. The emergent changes in food and water resources are aggregated and fed back to the original models with minimal modification of the structure of those models. It is our conviction that the framework presented can form the basis for a new wave of decision tools that capture complex socio-environmental change within our globalised world. In doing so they will contribute to illuminating pathways towards a sustainable future for humans, ecosystems and the water they share.
\end{abstract}

\section{Introduction}

Ensuring sustainable food and water security is an urgent and complex challenge (Shiklomanov, 2000; United Nations Water, 2015). The magnitude of the challenge is outlined in the Sustainable Development Goals, which set a target of zero hunger globally whilst at the same time drastically reducing impacts of food production on aquatic and terrestrial ecosystems as well as the climate system (United Nations, 2015). Food security and water security are inextricably intertwined, with variability in agricultural production impacting water resource use and vice versa (Liu and Savenije, 2008). Food trade, both international and domestic, also plays a central role in determining water use because when we trade food, we trade the water embedded in the production of that food (Fader et al., 2013; Hoekstra and Mekonnen, 2012). The global system of food production and trade is complex and drives interdependency among heterogeneous regions, meaning that socio-economic or environmental changes in one part of the globe can have cascading impacts for food and water security throughout the world (Fig. 1b) (D'Odorico et al., 2010; J. Liu et al., 2015; Marchand et al., 2016; Young et al., 2006). Equally, there is interdependency across sectors with 
(a)

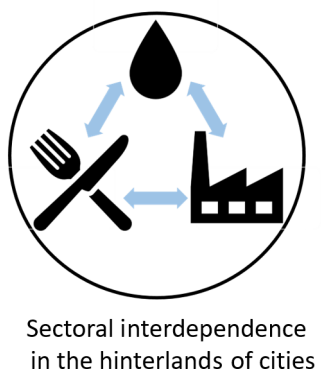

(b)

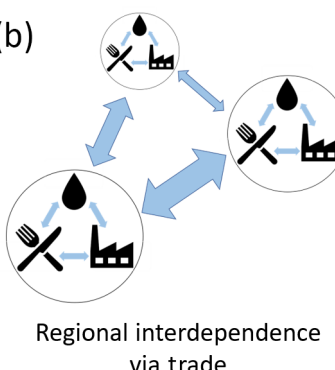

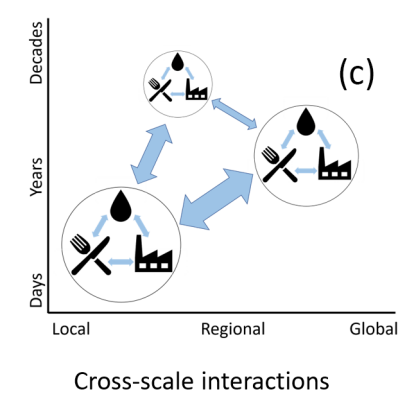

Figure 1. Complex dynamics within the global food system that lead to emergent water use patterns. (a) Sectoral interdependence in water resources within the food-water-energy nexus; (b) regional interdependence in water resources owing to the importance of trade for food security; (c) cross-scale feedbacks whereby fine-scale interactions bring about emergent higher-level change. Higher-level, emergent changes may feed back on the fine scale (Sivapalan and Blöschl, 2015).

the mechanisation of agriculture leading to a tighter coupling of the food, water and energy sectors in recent years, often referred as the food-water-energy nexus (Fig. 1a) (Bazilian et al., 2011). Within this interdependent system, interactions occur across spatial and temporal scales (d'Amour et al., 2016; Sivapalan and Blöschl, 2015) (Fig. 1c). For example, the combined effect of small-scale abstraction of ground and surface water to secure short-term food and water security can lead to large-scale and long-term depletion of water resources, which ultimately undermines food and water security (Sivapalan and Blöschl, 2015; Sophocleous, 2012).

Given the complexity of the food system, it is challenging to develop effective food and water management strategies because policies can leak across regions, sectors and scales (Eakin et al., 2009; Hejazi et al., 2015; Meyfroidt et al., 2013). Models and decision tools exist to inform policymakers on these issues. For example, integrated assessment models (IAMs) have made significant progress in capturing sectoral interdependencies with the food-waterenergy nexus (Bazilian et al., 2011; Lotze-Campen et al., 2008; Stehfest et al., 2014). Computational general equilibrium (CGE) models capture socio-economic interdependencies across regions (Hertel, 1997). In the hydrological sciences, water footprint studies capture regional interdependence whilst socio-hydrological studies capture crossscale socio-hydrological interactions (Hoekstra and Chapagain, 2006; Sivapalan et al., 2012). However, to our knowledge, regional and sectoral interdependencies and cross-scale feedbacks associated with food and water security have not been captured in a single modelling framework. As a result, existing approaches miss important dynamics (Konar et al., 2016a; Srinivasan et al., 2017). It is urgent that we capture these dynamics in a single modelling framework so that decision makers have appropriate tools to help them navigate the increasingly complex global food system and develop policies that ensure we stay within the natural limits of our planet's water resources (Steffen et al., 2015; Wagener et al., 2010).
In this paper, we present a modelling framework for capturing regional and sectoral interdependencies and crossscale feedbacks in the global food system that contribute to emergent water use patterns. The framework builds upon existing approaches in the fields of integrated assessment and hydrology and combines them via a multi-agent network of city agents and infrastructural trade links. We focus on cities because they are centres of food and water demand and important agents of change within the global food system, with $54 \%$ of the world's population urbanised, consuming a disproportionately large $75 \%$ of the world's resources (United Nations, 2012; UNEP, 2013).

Cities play a key role in driving regional interdependency via trade. In fact, cities and trade co-evolved, with demand from cities determining the location of physical trade networks that constrain our ability to extract food and water resources from the environment and redistribute them around the globe to meet demand (Barber et al., 2014; Barredo and Demicheli, 2003; Friedmann and Wolff, 1982; Fujita et al., 2001; Rees and Wackernagel, 2008). As city populations grow, infrastructural networks continue to upgrade capacity and extend further into natural systems, increasing our ability to extract natural resources but also increasing regional interdependence (Ibisch et al., 2016; Laurance et al., 2015). The infrastructural networks that radiate from cities serve to link environmental resources in city hinterlands to global food markets, thus playing a key role in facilitating crossscale socio-environmental feedbacks within the global food system (Brenner, 1999; Güneralp et al., 2013; Harvey, 1990).

Cities are also crucibles for cross-sectoral socio-economic interactions. Socio-economic conditions across different sectors of the economy constrain cities' demand for and capacity to produce food (Stehfest, 2014; UNEP, 2013). Socioeconomic conditions also constrain the ability of cities to trade food on regional and global markets (FAO, 2015). Trade cannot occur directly between two cities unless the socio-economic links exist and not at all if the infrastructural links are missing (De Benedictis and Tajoli, 2011). 

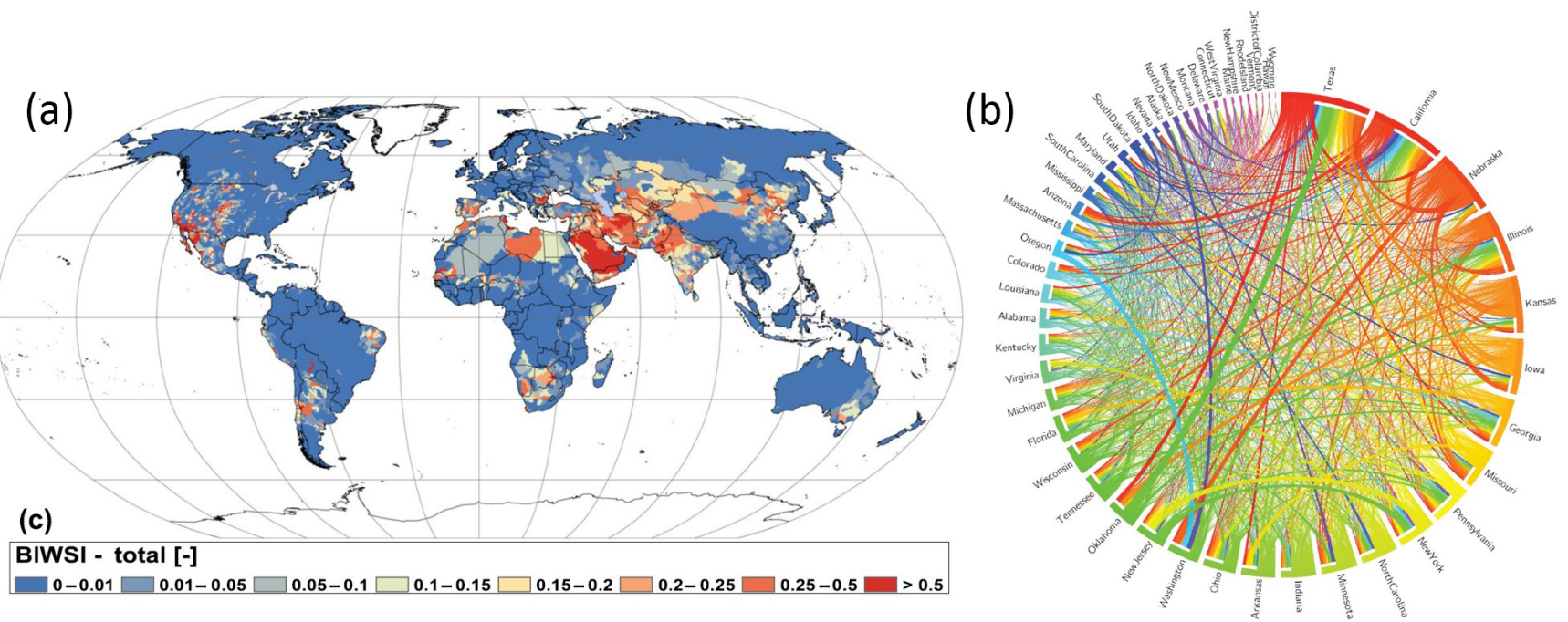

Figure 2. Water footprint studies. Water footprint studies exploit hydrological models to estimate blue and green water use in agriculture. These data are combined with data on food trade to estimate the fluxes of virtual water embedded in food trade. (a) The unsustainable water footprint of agriculture is shown in red, where groundwater abstraction exceeds aquifer recharge (taken from Wada and Bierkens, 2014). (b) Virtual water flows within the United States. States are ranked according to the total trade volume and plotted clockwise in descending order. The size of the outer bar indicates the total virtual water trade volume of each state as a percentage of total US trade. Destination volume is indicated with links emanating from the outer bar of the same colour. Origin volume is indicated with a white area separating the outer bar from links of a different colour (taken from Dang et al., 2015).

Of course, physical infrastructural and socio-economic networks cannot be disentangled. Strengthening of socioeconomic ties invariably leads to strengthening of infrastructural links, whilst the cost of investment in that infrastructure serves to stabilise those socio-economic ties (Khanna, 2016).

In the following Sect. 2, we present an overview of existing models and approaches to understand food and water security. We highlight some important knowledge gaps in these approaches that our framework aims to fill. In Sect. 3 we present our framework in detail, outlining how we aim to capture regional and sectoral interdependencies and crossscale feedbacks in a single framework. In Sect. 4 we outline potential applications of a realised version of the framework. In Sect. 5 we outline steps required to make this ambitious vision a reality.

\section{Challenges to capturing the complexity of food and water security using existing models and approaches}

\subsection{Regional interdependence}

As the food system becomes increasingly globalised and urbanised, trade, both domestic and international, drives interdependency for food and water security among trading regions (FAO, 2015; Sartori and Schiavo, 2015). Water footprint studies have played an important role in quantifying the volume of water used in food production and embedded in traded food, known as virtual water trade (Allan, 1998; Fader et al., 2011; Hanasaki et al., 2010; Konar et al., 2016b). These studies apply hydrological models to estimate the amount of green (recently precipitated, rapidly replenished water in the upper soil layer) or blue water (slowly replenished ground and surface water resources) used in food production (Fader et al., 2011; Hoff et al., 2010). On a global scale, $84 \%$ of food production relies on green water, which has generally less negative impacts on the environment compared with blue water. In terms of internationally traded food, $16 \%$ of traded food comes from green water resources and $6 \%$ from blue water resources (Fader et al., 2011). As a result, on a global scale, international trade saves water (de Fraiture et al., 2004; Hanasaki et al., 2010; Konar et al., 2011). However, recent studies have revealed that an increasing proportion of traded food is produced from unsustainably abstracted blue water resources (Dalin et al., 2017; Wada et al., 2010, 2012). Owing to regional interdependency of the food system, these unsustainable practices threaten the future food and water security of trading regions (Gleeson et al., 2012; Wada and Bierkens, 2014) (Fig. 2a). The increase in unsustainable water abstraction is principally owing to increased demand arising from population growth, with climate change projected to exacerbate stress on food and water resources in the future (Gerten et al., 2011).

A knowledge gap in these water footprint studies is that there tends to be a focus on international bilateral trade, meaning the much larger domestic trade fluxes are often neglected (Konar et al., 2016a). In the developed world, almost all food reaches consumers through trade whilst in the devel- 
oping world, trade is also increasing in importance as people move to cities and the numbers of people involved in subsistence agriculture decreases (Chen, 2007; IFPRI, 2017; Seto and Reenberg, 2014; United Nations, 2012). The lack of studies on domestic trade is in large part owing to the lack of data. However, increasingly there are attempts to quantify virtual water flows within countries (Fig. 2b) (Dalin et al., 2014; Dang et al., 2015) and the water footprints of cities (Hoff et al., 2014). Identifying the fine-scale networks that constrain where water resources are extracted from the environment to meet remote demand is essential for managing water under globalisation. This will improve our ability to diagnose the remote drivers of water resource use and understand how local water resource use may be teleconnected with socio-environmental change in another part of the global food system (d'Amour et al., 2016). Thus, the first knowledge gap our framework seeks to fill is to capture the fine-scale networks that constrain water resource extraction and virtual water trade.

\subsection{Sectoral interdependence}

Owing to the increased mechanisation of agriculture and the development of more diverse energy sources, the interdependencies among the food, water and energy sectors are stronger than ever (Bazilian et al., 2011; Kraucunas et al., 2015; United Nations Water, 2015). Currently $30 \%$ of energy produced is used within the food sector, with fluctuations in energy costs having direct impacts on agriculture and thus water resources (Frieler et al., 2015). In addition, the energy sector itself requires considerable water resources (Bijl et al., 2016). Fossil fuel extraction such as coal mining and shale gas fracking are highly water intensive, whilst biofuel production competes with food production for land and water resources (Bonsch et al., 2016; Hejazi et al., 2015). Failure to capture sectoral interdependencies means we may fail to identify synergistic solutions; or worse still, policies in one sector may have unintended negative consequences in another. For example, investment in climate change mitigation measures such as biofuel production may lead to increased competition for water between the food and energy sectors and exacerbate unsustainable water use (Hejazi et al., 2015).

IAMs are powerful tools to explore sectoral interdependencies (Bazilian et al., 2011). Until now, IAMs have principally been focused on projecting greenhouse gas emissions; however, increasingly, the agricultural sector is being captured within IAMs (Stehfest et al., 2013; Stehfest and Bouwman, 2006; Wise et al., 2009). For example, the IMAGE IAM contains an agriculture and land module that is internally coupled with an energy supply and demand module. IMAGE calculates changes in agriculture based on two-way interactions between the agriculture and energy sectors (Stehfest et al., 2014). IMAGE has also been coupled with the MAGNET agro-economic model, a CGE model that uses in- formation from IMAGE on land availability and suitability, labour supply, and technological change to estimate international food trade, demand and supply (Stehfest et al., 2013; von Lampe et al., 2014; Woltjer et al., 2014). An integrated approach has also been applied by Bonsch et al. (2016) using MAgPIE (Lotze-Campen et al., 2008), a global land and water use allocation model, to understand the trade-off between agricultural expansion and intensification via water abstraction to meet biofuel targets. Like Hejazi et al. (2015), their integrated approach showed that changes in the energy sector can lead to competition for water resources within the food sector. The MAgPIE approach also underlined the importance of capturing dynamic vegetation and hydrological processes in the same modelling framework as the two are intrinsically intertwined, with changes in vegetation impacting water resources and vice versa (Fader et al., 2011; Konar et al., 2013; Lotze-Campen et al., 2008).

Although IAM approaches capture important sectoral interdependencies, they cannot provide a representation of non-linear transformative change typical of socioenvironmental systems and the dynamics associated with it (Filatova et al., 2013; Folke, 2006; Rockström et al., 2017). Incorporating these processes in IAMs would risk including too much complexity, possibly leading to a trade-off with transparency (van Vuuren et al., 2016). An alternative approach is to couple IAMs with models that capture these important processes, without changing the internal structure of IAMs. Some progress has already been made in this direction by coupling land use models with IAMs, in which the IAM set regional socio-economic constraints for the land use model. Based on these constraints, the emergent finescale patterns from the land use model are aggregated on the regional scale captured in the IAM. This approach has resulted in improved regional projections in IAMs as land allocation models capture important within-region heterogeneity (Hasegawa et al., 2017; Stehfest et al., 2013).

In order to model the complexity of socio-environmental systems, it is necessary to capture dynamics such as agency, emergence, non-linearities and feedbacks (Berger, 2001; Brown et al., 2005; Farmer and Foley, 2009; Farmer and Geanakoplos, 2009; Folke, 2006; Helbing, 2013; Sivapalan et al., 2012). However, the pathway to capturing these dynamics on a global scale is not obvious (Verburg et al., 2016). For example, it is not practical from a computational or data perspective to represent farmers as agents on a global scale. Thus, the second knowledge gap our framework aims to fill is to incorporate the complex dynamics associated with socioenvironmental systems on a global scale within the IAM framework. We aim to achieve this by focusing on cities and infrastructural networks. As stated, cities are key agents of change and lie at the intersection of scales within the global food system, whilst infrastructural networks constrain our ability to extract resources from the environment and redistribute them to meet demand (Brenner, 1999; Khanna, 2016; United Nations Water, 2015). An advantage of using cities as 
agents is that they have a number of important features that are generalisable. Firstly, all cities, irrespective of where or when they existed, have a common utility function, which is to sustain the import of resources to maintain growth (Batty, 2008). Secondly, cities competitively interact for resources and services irrespective of whether they are in the same administrative region or not (Begg, 1999). Thirdly, the investment in infrastructure, which is a defining characteristic of cities, makes them highly path dependent (Khanna, 2016). This path dependency provides opportunities for narrowing the possibility space of future projections (Brown et al., 2005).

\subsection{Cross-scale socio-environmental feedbacks}

Cross-scale socio-environmental feedbacks describe a broad range of processes in which small-scale or short-term actions bring about large-scale or long-term emergent change (Sivapalan and Blöschl, 2015). These emergent higher-level changes may feed back on the finer scale. In terms of water resources, socio-hydrological studies have played an important role in helping to understand emergent water use patterns by capturing cross-scale socio-environmental feedbacks (Di Baldassarre et al., 2013a, b; Montanari et al., 2013; Sivapalan et al., 2012; Troy et al., 2015). They have done so by explicitly considering bidirectional feedbacks between humans and the environment in hydrological basins. An example of emergent dynamics is a "pendulum swing", in communities that have alternated between water extraction for agriculture in the early stages of development, followed by subsequent efforts to mitigate or reverse the consequent degradation of the riparian ecosystems (Kandasamy et al., 2014; Liu et al., 2014). This has been explained by counteracting productive and restorative forces, mediated via technology, environmental awareness and the intervention of governing institutions (Elshafei et al., 2015; J. Liu et al., 2015; van Emmerik et al., 2014).

However, socio-hydrological studies maintain a disciplinary focus on water, failing to capture important sectoral interdependencies as IAMs do (Troy et al., 2015). Equally, they have so far assumed the systems of concern are isolated entities in space, e.g. an agricultural river basin, whereas in a globalised world, many different such entities may be linked through trade, as demonstrated in water footprint studies (Konar et al., 2016a). Capturing linkages to regional and global markets is critical to understanding cross-scale feedbacks because the more connected water resources are to markets via trade, the more sensitive they are to cross-scale feedbacks (Eakin et al., 2009; Pande and Sivapalan, 2016). For example, the 2010 drought in Russia and Kazakhstan led to a spike in the price of wheat on global markets (Nelson et al., 2014). Food producers in other wheat-producing regions of the world that were well connected to global markets via physical and socio-economic trade links were impacted by this price rise as they could sell their products to global

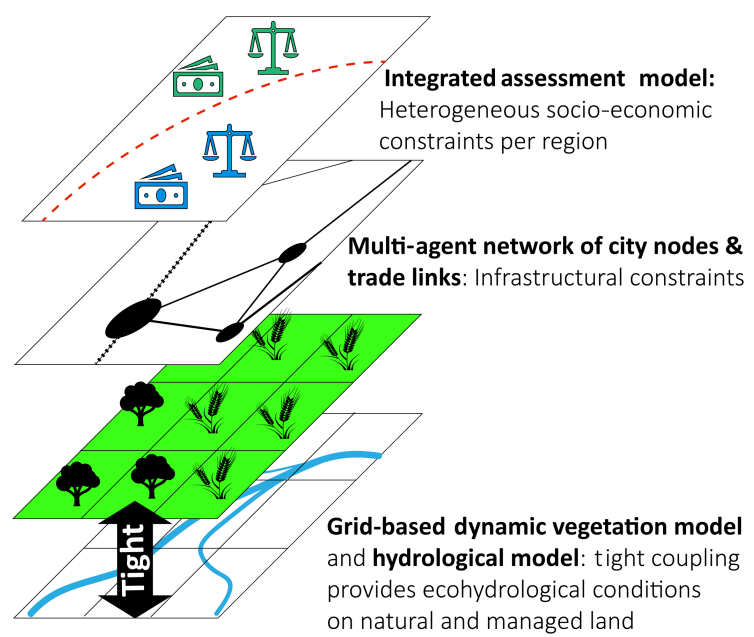

Figure 3. City agent attributes. In our framework, city agents receive ecohydrological conditions from a tight coupling between a dynamic vegetation model and hydrological model. They receive socio-economic constraint information from an integrated assessment model. Ecohydrological conditions on natural and managed land determine food production potential and associated water use. The IAM captures heterogeneous socio-economic conditions that constrain the ability of cities to exploit ecohydrological conditions for food production. At the time of writing, to our knowledge, a tight coupling between a dynamic vegetation model and a complex hydrological model has yet to be implemented.

markets at increased profit. Thus, environmental change in Russia impacted global markets, which drove local water resource use in other parts of the world. There has been a recognition of the important role trade plays in facilitating crossscale feedbacks in literature related to land use change (Geist and Lambin, 2002; Lambin and Geist, 2008). These studies have highlighted that distant market demand drives local land use change, and in order to predict land use change we need to model land as an open system with flows of resources coming in and out (Lambin and Meyfroidt, 2011). However, modelling of these issues in relation to water resources is still in its infancy (Konar et al., 2016a). Thus, the third challenge is to capture the crucial role of trade networks in facilitating cross-scale feedbacks between local water resources and regional and global markets.

\section{Modelling framework}

\subsection{The city agent}

\subsubsection{City agent attributes}

The core structure of our framework is a multi-agent network of city nodes and trade links (Fig. 3). In our framework, cities are agents and are comprised of an urban area and associated hinterland. City agents sit at the intersection of scales between ecohydrological resources in their hinter- 


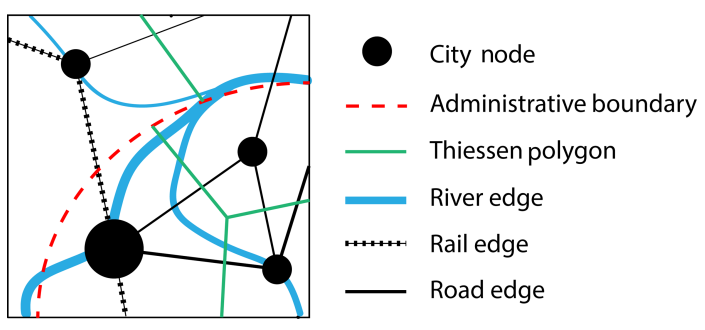

Figure 4. The city and its hinterland. City agent hinterlands are defined by a hierarchical overlay of supra- to subnational administrative boundaries and Thiessen interpolation among city nodes based on the gravity equation of trade. Cities are linked by a physical infrastructural network in which edges represent the cost distance of trade via roads, rail and shipping routes.

lands and global markets via radiating trade networks. The ecohydrological conditions in hinterlands of city agents are determined from a coupled hydrological-vegetation model for natural and managed land. Socio-economic conditions in the hinterlands of cities are determined from an IAM and CGE. Socio-economic conditions constrain agents' ability to exploit environmental conditions within their hinterland for food production. City agents have a common utility function: to satisfy local and market demand for food, which in turn leads to emergent water use. City agents satisfy demand via food production and trade. How each city satisfies demand differs based on the heterogeneous socioeconomic and environmental conditions in their hinterland and the socio-economic and infrastructural networks that link them. The fine-scale interactions among cities and their environment bring about higher-level emergent patterns that provide input conditions for the next simulation step of the IAM and CGE.

\subsubsection{The city and its hinterland}

Each city agent has an associated hinterland. The definition of a hinterland varies in literature but depends upon resource demand in the city and on the ease of transportation between the city and the resource production area, which is determined by geographic, infrastructural and socio-economic factors (Billen et al., 2009). To capture these elements, we define city hinterlands based on the hierarchical overlay of supra- to subnational administrative borders and Thiessen polygon operation among cities based on the gravity equation of trade with mass equal to demand and distance equal to the cost distance of trade via road, rail and inland water ways (Fig. 4) (Berthelon and Freund, 2008; Chaney, 2013). We base hinterlands on administrative borders so that the framework can capture the impact of heterogeneous policy or socio-economic conditions on the administrative scale. For many cities, and depending on the food commodity, the effective hinterland will extend beyond these contiguous administrative regions (Billen et al., 2009; Güneralp et al.,
2013). However, policy is applied on the scale of these administrative boundaries and cities operate within these policy constraints. If policies stimulate free trade between administrative regions, then the effective hinterland of a city can expand (Knox and McCarthy, 2012). Therefore, the framework allows for the exploration of the impact of policy on different scales on food and water use and virtual water flows. By also basing the size of hinterlands on the cost distance of trade via road, rail and shipping, we capture the key role that infrastructural networks play in linking demand in cities with environmental resources.

Hinterlands vary in terms of size and composition. The hinterland of a city in Western Australia will be large, with a high proportion of natural land cover and low population density, whilst a hinterland in eastern China will be smaller with a high proportion of agricultural and urban land cover and high population density. From a socio-economic perspective, per capita demand will differ among hinterlands based on diet, affluence, etc. derived from the IAM. Equally, the agricultural intensification potential of a hinterland in the Netherlands will be greater compared with a sub-Saharan African region owing to factors such as mechanisation of agriculture, access to fertilisers, etc. (Stehfest et al., 2014).

\subsection{Food production and water use}

Within our framework, city agent food production decisions are constrained by ecohydrological conditions within their hinterlands. To capture ecohydrological conditions, we recommend tight coupling between a dynamic vegetation model (DGVM) such as the Lund-Potsdam-Jena managed Land (LPJ-ML) model and a complex hydrological model such as the PCRaster Global Water Balance (PCR-GLOBWB) model (Bierkens and van Beek., 2009; Bondeau et al., 2007) (Fig. 3). In this way, the model would capture the two-way water fluxes between vegetation and water in the soil layer and infiltration to the groundwater reservoir, which is key for computing groundwater recharge rates (Hanasaki et al., 2008). This is a considerable modelling challenge. Vegetative water demand and rooting depths from the DGVM would need to be sent to the hydrological model. Using the detailed soil water profile from the hydrological model, an improved estimate of water availability could be made. If water supply is lower than demand from the DGVM, then vegetation growth will be limited due to soil water stress. If water supply is higher than demand from the DGVM, then water infiltrates the groundwater reservoir in the hydrological model. Each city hinterland has a potential yield and associated water resource usage based on these ecohydrological constraints.

Socio-economic constraints on food production are taken from the IAM based on factors such as the mechanisation of agriculture, access to fertilisers, etc. The demand for each food commodity in a city and its hinterland is equal to (per capita demand taken from IAM $\times$ population), with population based on spatially explicit grid-scale population esti- 
(a) Expansion potential

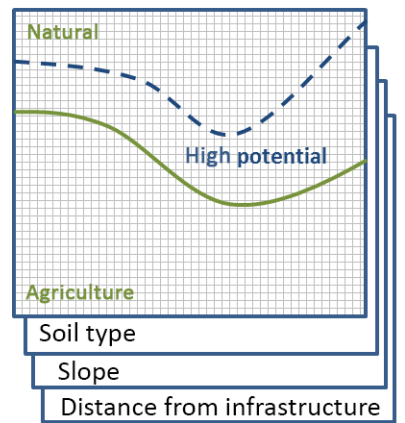

(b) Intensification potential

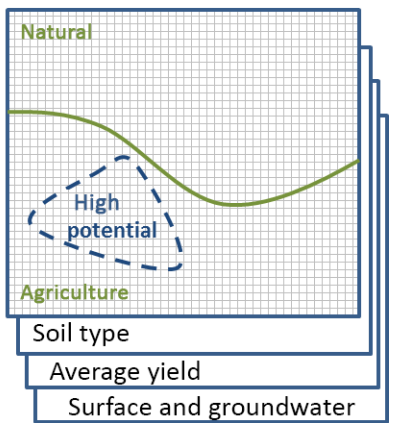

Figure 5. Food production decisions. City agents decide on agricultural expansion (a) or intensification (b) based on demand and spatially explicit crop production potential in their hinterlands.

mates (Bijl et al., 2017; Brinkhoff, 2016; Klein Goldewijk et al., 2011; Stehfest, 2014; UN Population Division, 2015). Cities and their hinterlands are either in surplus or deficit for a crop type based on (local production - local demand) (Dermody et al., 2014). Cities with predominantly urbanised hinterlands will have a net demand for food resources whilst others, with large areas of agriculture within their hinterlands, will have a net surplus in food resources. Demand is also based on trade demand calculated in the trade component of the framework (Sect. 3.3).

Cities adapt to changes in food demand through agricultural expansion and/or contraction, (de)intensification, or trade. Agricultural expansion and intensification potential are estimated using land use algorithms. The algorithms used to calculate agricultural expansion and intensification potential in IAMs such as IMAGE may be extended to include detailed infrastructural data as well as more complex hydrology in determining agricultural suitability (Fig. 5) (Barber et al., 2014; Wada et al., 2012; Walker et al., 2013). In our framework, cities with increasing demand, low (high) agricultural intensity potential and high (low) expansion potential are likely to expand (intensify) agriculture. Cities that are constrained from expanding or intensifying agriculture will increase imports to sustain growth. The agent decision process generates land use maps that are prescribed to the ecohydrological model (Biemans et al., 2013; Wada et al., 2012).

The method for capturing food production outlined blends macro-scale interdependencies between the agricultural and energy sectors with small-scale ecohydrological and demographic conditions to estimate land use change, similar to the approach by Hasegawa et al. (2017) and Verstegen et al. (2016). Importantly, our approach also captures how market demand is transmitted heterogeneously within a region or country via infrastructural networks (see Sect. 3.3 for more details). This is a critical step in understanding the critical role infrastructural networks play in determining water use and virtual water trade patterns (Konar et al., 2016a; Lambin and Meyfroidt, 2011).

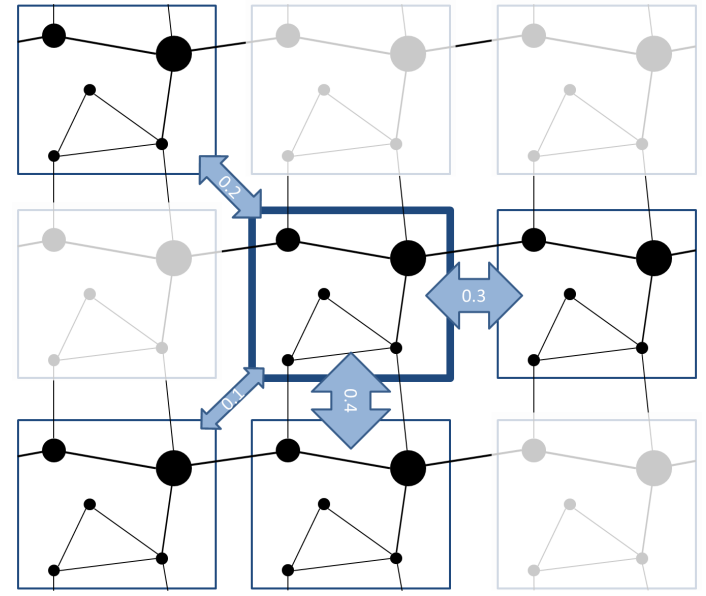

Figure 6. Virtual water trade network. The trade network is hierarchical, containing an upper-level network with edge weights capturing the probability of trade among countries. The edge weights of the upper-level network are calculated using a CGE model based on factors such as historical trade patterns, trade agreements, etc. Edge weights of the lower level capture the cost distance of trade via roads, rail and shipping lanes. All resources travel via the lowerlevel physical infrastructural network in a realised version of the model framework.

\subsection{Virtual water trade}

The trade network that links city agents is hierarchical. The network comprises a lower-level physical infrastructural network and an upper-level network with link weights reflecting bilateral socio-economic trade links (Fig. 6). The lower level of the trade network is defined by physical trade infrastructure of roads, rail and shipping lanes (Berthelon and Freund, 2008; Karpiarz et al., 2014; Limão and Venables, 2001). The data required to build this network, such as open street maps and a database of cargo ship movements, are openly available (Brinkhoff, 2016; Haklay and Weber, 2008; Kaluza et al., 2010). In a realised version of the framework, each edge of the lower-level network has a different transport cost. For example, the cost of bulk trade is approximately $7 \times$ less by ship than by road (Limão and Venables, 2001). In addition, intermodal transport costs are applied for transferring goods between transport modes (Janic, 2007). Infrastructure development can be projected using infrastructure growth algorithms or manually added to explore the impacts of prospective plans such as the new trans-Eurasian Silk Road Economic Belt on virtual water trade and water use (Ahmed et al., 2013; Arima et al., 2008; Brugier, 2014; Walker et al., 2013). Because the infrastructural network constrains where resources can be extracted from the environment and redistributed to meet demand, all resource flows travel via the lower-level physical infrastructural network in a realised version of the model framework (Barber et al., 2014; Khanna, 2016). The upper-level network consists of bilateral trade links among countries. Edge weights among countries are calculated us- 
ing a CGE model. CGEs are constrained with historical data on bilateral trade balances, competitiveness (relative price developments) and trade policies to estimate trade patterns (Hertel et al., 2007; Woltjer et al., 2014). If the CGE simulates high trade volumes between two countries, then the edge weight between those countries in our framework will reflect a high probability of bilateral trade.

In a realised version of the framework, the food produced in the hinterlands of cities is either consumed locally or exported to meet market demand. Cities with a demand import from cities with a surplus based on the cost distance among cities (Berthelon and Freund, 2008). Thus, the probability of trade among cities decays with increasing cost distance (Karpiarz et al., 2014; Limão and Venables, 2001). City agents within the same country trade with one another based solely on supply and demand for each food commodity and the cost distance of trade among cities. Cities in different countries are also constrained by bilateral trade probabilities of the upper-level network (Fig. 6). For example, the probability of trade between Japan and American cities will be determined by the upper-level network based on CGE output. However, it is more likely that the demand will be met from hinterlands on the west coast of the United States owing to the lower cost distance of trade. The emergent trade patterns are aggregated on the country and region scales of the CGE and fed back into it for the next simulation year. Because city agent trade decisions are stochastic, the framework allows for alternate emergent trade patterns within the constraints of the same network. Thus, for given constraints there will be a range of possible solutions. The stronger (weaker) the constraints, the narrower (wider) the solution space. In this way, the solution space for given environmental, socio-economic and infrastructural constraints can be explored (An, 2012). Equally, if conditions change on the small scale, this will result in alternative emergent patterns on the large scale (Fig. 7). In this way, agency, cross-scale processes, and socio-economic, environmental and infrastructural constraints are married with conventional general equilibrium modelling approaches. This is a novel and potentially important step in capturing non-equilibrium dynamics within pre-existing equilibrium modelling approaches (Farmer and Geanakoplos, 2009). It also allows us to begin to uncover the important role of cross-scale feedbacks in linking local water resource change to the dynamics of regional or global markets (Konar et al., 2016a).

\section{Applications of the framework}

The framework is designed to be used with IAMs, which are influential decision tools but are unable to capture nonlinear, emergent change typical of socio-environmental systems (Rockström et al., 2017; van Vuuren et al., 2016; Verburg et al., 2016). Our approach does not require IAMs to be re-engineered, but rather simulates complex socio- environmental processes within the constraints exogenously applied by IAMs. The emergent patterns may be aggregated on the scale of IAMs and used as input conditions for the next simulation step. In this way, the framework blends bottom-up processes captured by the multi-agent network of cities with the top-down approach captured by IAMs. Thus, a realised version of the framework has the potential to illuminate how the higher-level patterns demonstrated in IAMs emerge. In terms of informing policy, this is an important step as it allows policymakers to explore the impacts of policy changes on the different spatial and temporal scales on which policy is applied. In doing so, models based on the framework can help illuminate road maps, considering complex dynamics, to reach regional and long-term goals outlined in IAMs (Rockström et al., 2017). For example, it allows the exploration of how scenarios, such as the recently published Shared Socioeconomic Pathway (SSP), which outlines future environmental change according to different socio-economic development storylines (O'Neill et al., 2015), can be implemented on finer scales and taking account of sectoral and regional interdependencies and cross-scale feedbacks. This can be a potentially important step in extending the usefulness of IAMs whilst avoiding adding unwanted complexity to those models (van Vuuren et al., 2016).

The multi-agent network of cities at the core of the framework enables the exploration of the emergent solution space for realising food and water security requirements based on socio-economic and environmental constraints. The solution space reveals how constrained regions or sectors are based on socio-economic, environmental and infrastructural factors to transition to sustainable and secure water use pathways (Brown et al., 2005; Garud et al., 2010). Within the solution space, sustainable and secure development pathways can be explored. A common approach for exploring multidimensional solution space is to use optimality algorithms (Dermody et al., 2011; Konak et al., 2006; Vrugt et al., 2003). Multi-objective optimality algorithms can be used to explore synergistically sustainable solutions across regions, sectors and scales. Such synergistic approaches are key to addressing the challenges set out in the UN Sustainable Development Goals (Costanza et al., 2016; Lu et al., 2015). Thus, the model can be used to inform policies that are sustainable in the administrative region, the economic sector and the scale on which those policies are applied, as well as interdependent regions, sectors and scales. Those regions or sectors that are locked into unsustainable or vulnerable water use pathways should be prioritised for intervention (Fig. 8) (Liebowitz and Margolis, 1995; Romero-Lankao et al., 2017; Sophocleous, 2012).

Given the importance of cross-scale feedbacks for understanding local water use, it is essential that smallerscale studies on food and water security can be linked with regional- and global-scale models (Pande and Sivapalan, 2016; Sivapalan and Blöschl, 2015; Verburg and Overmars, 2009). The model framework presented can be used to under- 


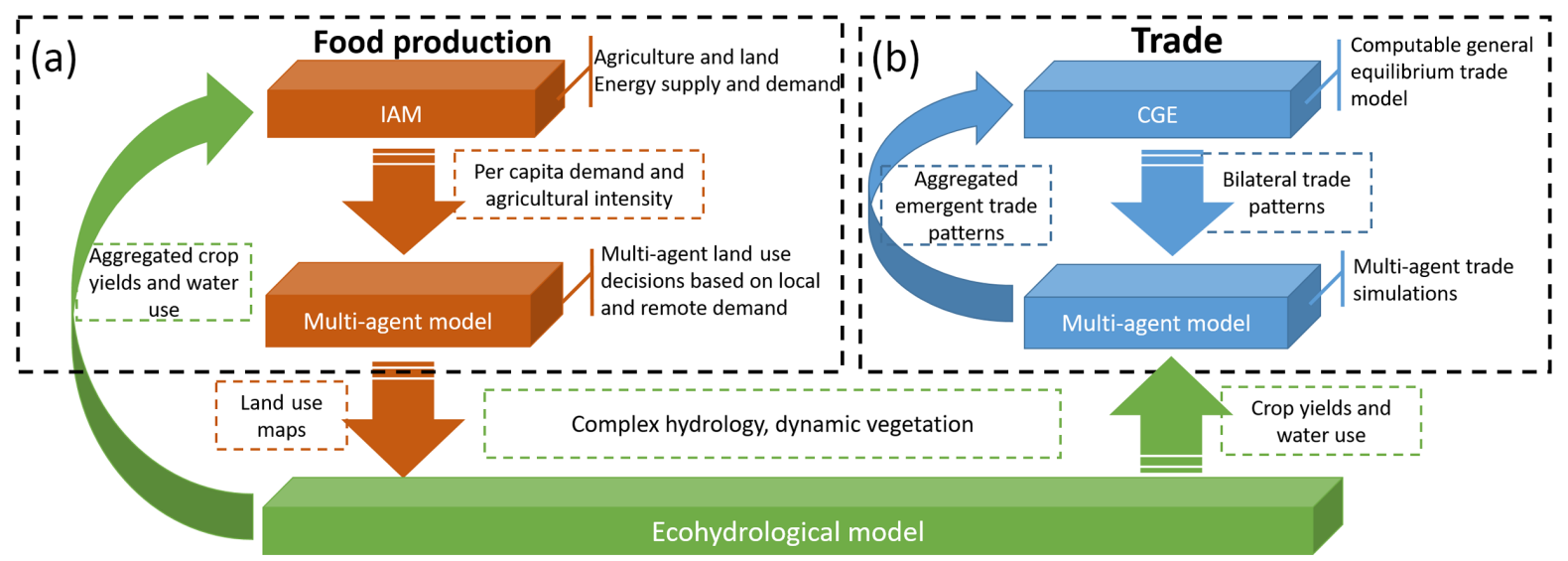

Figure 7. Modelling framework workflow. (a) The multi-agent network sits at the interface between an IAM and an ecohydrological model. The IAM calculates per capita food demand on a regional scale, which is converted into spatially explicit demand using population maps. The IAM also calculates agricultural intensity constraints. Based on these constraints and demand, agents make food production decisions that change ecohydrological conditions. The emergent crop production and water use patterns are aggregated and feed back to the IAM. (b) A CGE trade model provides edge weights for the upper-level trade network. Based on these bilateral trade constraints and demand, virtual water trade among city agents is simulated among agents via the infrastructural trade network. The emergent aggregated trade patterns feed back to the CGE as input for the next simulation year.

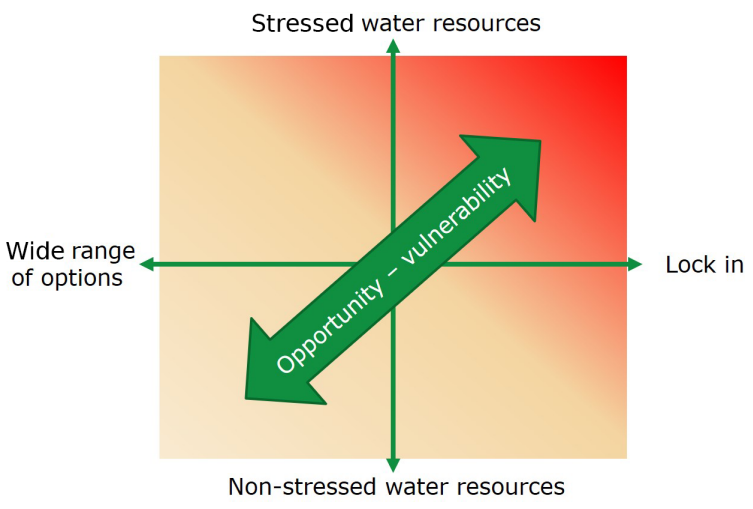

Figure 8. The solution space reveals how constrained regions or sectors are along their current water use pathway. The solution space emerges from the multi-agent simulations. The solution space may be explored to find pathways towards sustainable water futures that take account of regional and sectoral interdependencies and cross-scale feedbacks. Those regions or sectors that are locked into unsustainable or vulnerable water use pathways should be prioritised for intervention.

stand how detailed changes within a city or catchment link to large-scale market or environmental change. Thus, models built according to our framework can contribute to, and benefit from, the rapid growth of within-city studies such as studies of urban metabolism or socio-hydrological studies that focus on the catchment scale (Broto et al., 2012; Liu et al., 2014; van Emmerik et al., 2014; Zhang, 2013). In the case of urban metabolism studies, a detailed analysis of resource flows into and out of a city is performed. Models based on our framework can illustrate how urban resource flows are tele- connected with environmental change in other parts of the globe. Equally, urban resource budgets can be used to test model performance. In the case of socio-hydrological studies, the framework outlined can help illustrate how smallscale changes across multiple catchments can lead to emergent market changes, which in turn feed back on water use within a single catchment.

\section{Summary and recommendations}

The complex and interdependent nature of food and water security within our globalised and urbanised world requires new decision tools to inform policymakers. Models built using the framework outlined are ideally suited to informing policy on the "wicked problems" of regional and sectoral interdependencies and cross-scale feedbacks that contribute to unsustainable water use (Dentoni et al., 2012; Duit and Galaz, 2008; Lach et al., 2005; Sivapalan and Blöschl, 2015).

IAMs and hydrological models provide the groundwork for the proposed framework. However, extra efforts are required to achieve an operational model based on the framework presented. The main step required is the construction of a multi-agent network of city nodes and infrastructural links. A multi-agent network of city nodes and infrastructural links will provide a platform for a wide range of research questions on socio-environmental change. The resources required to build this network are openly available but need to be translated into a scalable and flexible network architecture. A summary description of a generalised framework for a multi-agent network of cities and infrastructural links is presented in Table 1. 
Table 1. Description of generalised framework for a multi-agent network of city nodes and infrastructural links. The description follows the ODD + D protocol (Müller et al., 2013) for describing agent-based models.

\section{Overview 1.1 Purpose}

A multi-agent network of cities and infrastructural links will provide a platform for a wide range of research questions related to global environmental change. The framework is designed to be coupled with IAMs, CGEs and grid-based environmental models. The framework enables the simulation of regional and sectoral interdependencies and cross-scale feedbacks within the constraints provided by these models.

1.2 State variables and scales

The multi-agent network consists of one type of agent, the city. City agents interact with the environment within their own hinterland and with other city agents by trading resources via the infrastructure network. Each agent has a geographic node location that is linked to a hinterland polygon from which agent attributes are derived. The distance among agents is based on the cost distance of trade via the infrastructural network. The network is scalable depending on the detail of analysis. The scaling is based on infrastructure hierarchies and population. For example, on a global scale, only freeway roads are captured and cities below a certain population threshold are aggregated into larger city nodes.

1.3 Process overview and scheduling

Each simulation year, cities receive socio-economic constraint information from an IAM. Cities have a certain resource demand based on their internal demand and demand from other cities in the network. Cities make resource use decisions based on demand, socio-economic constraints and environmental conditions in their hinterlands. The output of the multi-agent model may be aggregated on the scale of IAMs or CGEs and used as input for the next iteration of those models.

Design 2.1 Theoretical and empirical background

Concepts The model is built to test the hypothesis that socio-environmental interactions across regions, sectors and scales are mediated by cities and physical trade infrastructure that link environmental resources with socio-economic demand.

2.2 Individual decision-making

The decision model is based on the generalisable theory that cities competitively interact for environmental resources to sustain growth. City agent decisions are individual but socio-economic constraints on decision-making may be applied at a higher level, e.g. state level.

2.3 Learning

Optimisation algorithms may be applied to explore solution space within exogenously applied socio-economic and environmental constraints.

2.4 Individual sensing

City agents sense exogenous socio-economic constraint information from an IAM. City agents sense exogenous environmental conditions from an environmental model. Cities sense endogenous resource demand from other agents.

2.5 Individual prediction

Agents perceive temporal changes in resource demand.

2.6 Interaction

Interactions among agents are determined by each agent's surplus or deficit for a resource and the cost distance among agents in the network.

2.7 Collectives

Agents do not belong to collectives.

2.8 Heterogeneity

Agent attributes are heterogeneous and based upon socio-economic constraint information, environmental conditions and population within their hinterland. The local topology of the infrastructure trade network is also heterogeneous among agents.

2.9 Stochasticity

Socio-economic constraint information is applied as probability distributions, meaning agent decisions are stochastic and based on these probability distributions. Agent-agent trade decisions are stochastic and based on supply and demand and the cost distance between agents in the infrastructure network. The probability of trade decreases with increasing cost distance, assuming uniform supply and demand.

2.10 Observation

Emergent agent decisions are sent to an environmental model as land use change maps. The environmental model calculates environmental processes based on these land use changes. The observable output is environmental change in forest cover, water resources, crop yields, etc. The second observable output is resource consumption. Emergent resource consumption of agents is aggregated on a scale relevant for IAMs, e.g. the regional scale. The third observable output is trade patterns. Emergent trade patterns are aggregated on a scale relevant for CGEs, e.g. countries and regions.

Details $\quad 3.1$ Implementation

The framework is not yet implemented, and a software platform has not yet been chosen.

3.2 Initialisation

It is envisaged that a model based on the framework presented can be initialised for past conditions and run until present to test the model's performance. The model can also be run for scenarios that are implemented within the IAM framework. Because the model is stochastic, an ensemble of simulations can be run for the same socio-economic constraint information and used to explore different pathways for given constraints.

3.3 Input data

The input data to define city agents are the global city database and population density maps. Administrative boundaries combined with Thiessen polygon analysis are used to define hinterlands of cities. The infrastructural trade network consists of road and rail networks and shipping lanes and ports. Other infrastructure relevant for resource extraction such as energy redistribution infrastructure could also be captured with the framework. 
The structure of the multi-agent network should be designed in collaboration with scientists from different disciplines to ensure the relevant elements are incorporated to meet a range of research questions. To facilitate collaboration in building such a multi-agent network, there is a need for interdisciplinary dialogue and collaboration. Indeed, this is essential for achieving the Sustainable Development Goals, which present interdependent challenges across disciplines (Costanza et al., 2016; Lu et al., 2015). In our experience, the theories and methods associated with the science of complex systems provide an ideal approach for tackling interdisciplinary sustainability challenges (J. Liu et al., 2015). Complexity is not just a suite of theories and methods, it delivers an intuitive way of understanding interdependent systems and provides a platform for deep interdisciplinary collaboration that is required to meet today's sustainability challenges.

Data availability. No data sets were used in this article.

Author contributions. BJD and SCD conceived the framework in collaboration with all co-authors. BJD prepared the paper with contributions from all co-authors.

Competing interests. The authors declare that they have no conflict of interest.

Special issue statement. This article is part of the special issue "Social dynamics and planetary boundaries in Earth system modelling". It is not associated with a conference.

Acknowledgements. The authors would like to thank the editor, James Dyke, and three anonymous reviewers for their considerate and constructive comments, which helped improve the paper.

Edited by: James Dyke

Reviewed by: three anonymous referees

\section{References}

Ahmed, S. E., Souza, C. M., Riberio, J., and Ewers, R. M.: Temporal patterns of road network development in the Brazilian Amazon, Reg. Environ. Change, 13, 927-937, https://doi.org/10.1007/s10113-012-0397-z, 2013.

Allan, J. A.: Virtual water: a strategic resource global solutions to regional deficits, Ground Water, 36, 545-546, https://doi.org/10.1111/j.1745-6584.1998.tb02825.x, 1998.

An, L.: Modeling human decisions in coupled human and natural systems: review of agent-based models, Ecol. Model., 229, 25 36, https://doi.org/10.1016/j.ecolmodel.2011.07.010, 2012.

Arima, E. Y., Walker, R. T., Sales, M., Souza Jr., C., and Perz, S. G.: The fragmentation of space in the Amazon Basin: emergent road networks, Photogramm. Eng. Rem. S., 74, https://doi.org/10.14358/PERS.74.6.699, 2008

Barber, C. P., Cochrane, M. A., Souza Jr., C. M., and Laurance, W. F.: Roads, deforestation, and the mitigating effect of protected areas in the Amazon, Biol. Conserv., 177, 203-209, https://doi.org/10.1016/j.biocon.2014.07.004, 2014.

Barredo, J. I. and Demicheli, L.: Urban sustainability in developing countries' megacities: modelling and predicting future urban growth in Lagos, Cities, 20, 297-310, https://doi.org/10.1016/S0264-2751(03)00047-7, 2003.

Batty, M.: The size, scale, and shape of cities, Science, 319, 769771, https://doi.org/10.1126/science.1151419, 2008.

Bazilian, M., Rogner, H., Howells, M., Hermann, S., Arent, D., Gielen, D., Steduto, P., Mueller, A., Komor, P., Tol, R. S. J., and Yumkella, K. K.: Considering the energy, water and food nexus: towards an integrated modelling approach, Special Issue: Clean Cooking Fuels and Technologies in Developing Economies, Energ. Policy, 39, 7896-7906, https://doi.org/10.1016/j.enpol.2011.09.039, 2011.

Begg, I.: Cities and competitiveness, Urban Stud., 36, 795-809, https://doi.org/10.1080/0042098993222, 1999.

Berger, T.: Agent-based spatial models applied to agriculture: a simulation tool for technology diffusion, resource use changes and policy analysis, Agr. Econ., 25, 245-260, https://doi.org/10.1016/S0169-5150(01)00082-2, 2001.

Berthelon, M. and Freund, C.: On the conservation of distance in international trade, J. Int. Econ., 75, 310-320, https://doi.org/10.1016/j.jinteco.2007.12.005, 2008.

Biemans, H., Speelman, L. H., Ludwig, F., Moors, E. J., Wiltshire, A. J., Kumar, P., Gerten, D., and Kabat, P.: Future water resources for food production in five South Asian river basins and potential for adaptation - a modeling study, Sci. Total Environ., 468-469, Supplement, S117-S131, https://doi.org/10.1016/j.scitotenv.2013.05.092, 2013.

Bierkens, M. F. P. and van Beek, L. P. H.: Seasonal predictability of European discharge: $\mathrm{NAO}$ and hydrological response time, J. Hydrometeorol., 10, 953-968, https://doi.org/10.1175/2009JHM1034.1, 2009.

Bijl, D. L., Bogaart, P. W., Kram, T., de Vries, B. J. M., and van Vuuren, D. P.: Long-term water demand for electricity, industry and households, Environ. Sci. Policy, 55, 75-86, https://doi.org/10.1016/j.envsci.2015.09.005, 2016.

Bijl, D. L., Bogaart, P. W., Dekker, S. C., Stehfest, E., de Vries, B. J. M., and van Vuuren, D. P.: A physically-based model of long-term food demand, Global Environ. Chang., 45, 47-62, https://doi.org/10.1016/j.gloenvcha.2017.04.003, 2017.

Billen, G., Barles, S., Garnier, J., Rouillard, J., and Benoit, P.: The food-print of Paris: long-term reconstruction of the nitrogen flows imported into the city from its rural hinterland, Reg. Environ. Change, 9, 13-24, https://doi.org/10.1007/s10113-0080051-y, 2009.

Bondeau, A., Smith, P. C., Zaehle, S., Schaphoff, S., Lucht, W., Cramer, W., Gerten, D., Lotze-Campen, H., Müller, C., Reichstein, M., and Smith, B.: Modelling the role of agriculture for the 20th century global terrestrial carbon balance, Glob. Change Biol., 13, 679-706, https://doi.org/10.1111/j.13652486.2006.01305.x, 2007.

Bonsch, M., Humpenöder, F., Popp, A., Bodirsky, B., Dietrich, J. P., Rolinski, S., Biewald, A., Lotze-Campen, H., Weindl, I., 
Gerten, D., and Stevanovic, M.: Trade-offs between land and water requirements for large-scale bioenergy production, GCB Bioenergy, 8, 11-24, https://doi.org/10.1111/gcbb.12226, 2016.

Brenner, N.: Globalisation as reterritorialisation: the re-scaling of urban governance in the European Union, Urban Stud., 36, 431451, https://doi.org/10.1080/0042098993466, 1999.

Brinkhoff, T.: World City Population Database: Population Statistics for Countries, Administrative Areas, Cities and Agglomerations, available at: www.citypopulation.de (last access: 15 March 2017), 2016.

Broto, V. C., Allen, A., and Rapoport, E.: Interdisciplinary perspectives on urban metabolism, J. Ind. Ecol., 16, 851-861, https://doi.org/10.1111/j.1530-9290.2012.00556.x, 2012.

Brown, D. G., Page, S., Riolo, R., Zellner, M., and Rand, W.: Path dependence and the validation of agent-based spatial models of land use, Int. J. Geogr. Inf. Sci., 19, 153-174, https://doi.org/10.1080/13658810410001713399, 2005.

Brugier, C.: China's Way: The New Silk Road, No. 14, EU-Institute for Security Studies, available at: https://www.iss.europa.eu/ sites/default/files/EUISSFiles/Brief_14_New_Silk_Road.pdf (last access: 17 February 2017), 2014.

Chaney, T.: The Gravity Equation in International Trade: An Explanation, Working Paper No. 19285, National Bureau of Economic Research, https://doi.org/10.3386/w19285, 2013.

Chen, J.: Rapid urbanization in China: a real challenge to soil protection and food security, CATENA, 69, 1-15, https://doi.org/10.1016/j.catena.2006.04.019, 2007.

Costanza, R., Fioramonti, L., and Kubiszewski, I.: The UN sustainable development goals and the dynamics of well-being, Front. Ecol. Environ., 14, 59-59, https://doi.org/10.1002/fee.1231, 2016.

d'Amour, C. B., Wenz, L., Kalkuhl, M., Steckel, J. C., and Creutzig, F.: Teleconnected food supply shocks, Environ. Res. Lett., 11, 035007, https://doi.org/10.1088/17489326/11/3/035007, 2016.

Dalin, C., Hanasaki, N., Qiu, H., Mauzerall, D. L., and RodriguezIturbe, I.: Water resources transfers through Chinese interprovincial and foreign food trade, P. Natl. Acad. Sci. USA, 111, 97749779, https://doi.org/10.1073/pnas.1404749111, 2014.

Dalin, C., Wada, Y., Kastner, T., and Puma, M. J.: Groundwater depletion embedded in international food trade, Nature, 543, 700704, https://doi.org/10.1038/nature21403, 2017.

Dang, Q., Lin, X., and Konar, M.: Agricultural virtual water flows within the United States, Water Resour. Res., 51, 973-986, https://doi.org/10.1002/2014WR015919, 2015.

De Benedictis, L. and Tajoli, L.: The World Trade Network, World Econ., 34, 1417-1454, https://doi.org/10.1111/j.14679701.2011.01360.x, 2011.

de Fraiture, C., Cai, X., Amarasinghe, I., Rosegrant, M., and Molden, D.: Does international cereal trade save water? The impact of virtual water trade on global water use, Comprehensive Assessment Research Report 4, Colombo, Sri Lanka, http://www.iwmi.cgiar.org/assessment/ FILES/pdf/publications/ResearchReports/CARR4.pdf (last access: 30 March 2017), 2004.

Dentoni, D., Hospes, O., and Ross, R. B.: Managing wicked problems in agribusiness: the role of multi-stakeholder engagements in value creation, Int. Food Agribus. Man., 15, 1-12 2012.
Dermody, B. J., Tanner, C. J., and Jackson, A. L.: The evolutionary pathway to obligate scavenging in gyps vultures, PLoS ONE, 6 , e24635, https://doi.org/10.1371/journal.pone.0024635, 2011.

Dermody, B. J., van Beek, R. P. H., Meeks, E., Klein Goldewijk, K., Scheidel, W., van der Velde, Y., Bierkens, M. F. P., Wassen, M. J., and Dekker, S. C.: A virtual water network of the Roman world, Hydrol. Earth Syst. Sci., 18, 5025-5040, https://doi.org/10.5194/hess-18-5025-2014, 2014.

Di Baldassarre, G., Kooy, M., Kemerink, J. S., and Brandimarte, L.: Towards understanding the dynamic behaviour of floodplains as human-water systems, Hydrol. Earth Syst. Sci., 17, 3235-3244, https://doi.org/10.5194/hess-17-3235-2013, 2013a.

Di Baldassarre, G., Viglione, A., Carr, G., Kuil, L., Salinas, J. L., and Blöschl, G.: Socio-hydrology: conceptualising humanflood interactions, Hydrol. Earth Syst. Sci., 17, 3295-3303, https://doi.org/10.5194/hess-17-3295-2013, 2013 b.

D'Odorico, P., Laio, F., and Ridolfi, L.: Does globalization of water reduce societal resilience to drought?, Geophys. Res. Lett., 37, L13403, https://doi.org/10.1029/2010GL043167, 2010.

Duit, A. and Galaz, V.: Governance and complexity - emerging issues for governance theory, Governance, 21, 311-335, https://doi.org/10.1111/j.1468-0491.2008.00402.x, 2008.

Eakin, H., Winkels, A., and Sendzimir, J.: Nested vulnerability: exploring cross-scale linkages and vulnerability teleconnections in Mexican and Vietnamese coffee systems, Special Issue: Food security and environmental change, Environ. Sci. Policy, 12, 398412, https://doi.org/10.1016/j.envsci.2008.09.003, 2009.

Elshafei, Y., Coletti, J. Z., Sivapalan, M., and Hipsey, M. R.: A model of the socio-hydrologic dynamics in a semiarid catchment: isolating feedbacks in the coupled humanhydrology system, Water Resour. Res., 51, 6442-6471, https://doi.org/10.1002/2015WR017048, 2015.

Fader, M., Gerten, D., Thammer, M., Heinke, J., Lotze-Campen, H., Lucht, W., and Cramer, W.: Internal and external green-blue agricultural water footprints of nations, and related water and land savings through trade, Hydrol. Earth Syst. Sci., 15, 1641-1660, https://doi.org/10.5194/hess-15-1641-2011, 2011.

Fader, M., Gerten, D., Krause, M., Lucht, W., and Cramer, W.: Spatial decoupling of agricultural production and consumption: quantifying dependences of countries on food imports due to domestic land and water constraints, Environ. Res. Lett., 8, 014046, https://doi.org/10.1088/1748-9326/8/1/014046, 2013.

Farmer, J. D. and Foley, D.: The economy needs agent-based modelling, Nature, 460, 685-686, https://doi.org/10.1038/460685a, 2009.

Farmer, J. D. and Geanakoplos, J.: The virtues and vices of equilibrium and the future of financial economics, Complexity, 14, 11-38, https://doi.org/10.1002/cplx.20261, 2009.

Filatova, T., Verburg, P. H., Parker, D. C., and Stannard, C. A.: Spatial agent-based models for socio-ecological systems: challenges and prospects, Environ. Modell. Softw., Thematic Issue on Spatial Agent-Based Models for Socio-Ecological Systems, 45, 1-7, https://doi.org/10.1016/j.envsoft.2013.03.017, 2013.

Folke, C.: Resilience: the emergence of a perspective for socialecological systems analyses, Global Environ. Chang., 16, 253267, https://doi.org/10.1016/j.gloenvcha.2006.04.002, 2006.

Food and Agriculture Organisation of the United Nations: The State of Food Insecurity in the World. Meeting the 2015 International 
Hunger Targets: Taking Stock of Uneven Progress, Rome, www. fao.org/3/a-i4646e.pdf (last access: 30 March 2017), 2015.

Friedmann, J. and Wolff, G.: World city formation: an agenda for research and action, Int. J. Urban Regional, 6, 309-344, https://doi.org/10.1111/j.1468-2427.1982.tb00384.x, 1982.

Frieler, K., Levermann, A., Elliott, J., Heinke, J., Arneth, A., Bierkens, M. F. P., Ciais, P., Clark, D. B., Deryng, D., Döll, P., Falloon, P., Fekete, B., Folberth, C., Friend, A. D., Gellhorn, C., Gosling, S. N., Haddeland, I., Khabarov, N., Lomas, M., Masaki, Y., Nishina, K., Neumann, K., Oki, T., Pavlick, R., Ruane, A. C., Schmid, E., Schmitz, C., Stacke, T., Stehfest, E., Tang, Q., Wisser, D., Huber, V., Piontek, F., Warszawski, L., Schewe, J., Lotze-Campen, H., and Schellnhuber, H. J.: A framework for the cross-sectoral integration of multi-model impact projections: land use decisions under climate impacts uncertainties, Earth Syst. Dynam., 6, 447-460, https://doi.org/10.5194/esd-6-447-2015, 2015.

Fujita, M., Krugman, P., and Venables, A.: The Spatial Economy: Cities, Regions, and International Trade, MIT Press Books, The MIT Press, Cambridge, Massachusetts, USA, https:// econpapers.repec.org/RePEc:mtp:titles:0262561476 (last access: 30 March 2017), 2001.

Garud, R., Kumaraswamy, A., and Karnøe, P.: Path Dependence or path creation?, J. Manage. Stud., 47, 760-774, https://doi.org/10.1111/j.1467-6486.2009.00914.x, 2010.

Geist, H. J. and Lambin, E. F.: Proximate causes and underlying driving forces of tropical deforestation tropical forests are disappearing as the result of many pressures, both local and regional, acting in various combinations in different geographical locations, BioScience, 52, 143-150, https://doi.org/10.1641/00063568(2002)052[0143:PCAUDF]2.0.CO;2, 2002.

Gerten, D., Heinke, J., Hoff, H., Biemans, H., Fader, M., and Waha, K.: Global water availability and requirements for future food production, J. Hydrometeorol., 12, 885-899, https://doi.org/10.1175/2011JHM1328.1, 2011.

Gleeson, T., Wada, Y., Bierkens, M. F. P., and van Beek, L. P. H.: Water balance of global aquifers revealed by groundwater footprint, Nature, 488, 197-200, https://doi.org/10.1038/nature11295, 2012.

Güneralp, B., Seto, K. C., and Ramachandran, M.: Evidence of urban land teleconnections and impacts on hinterlands, Curr. Opin. Env. Sust., 5, 445-451, https://doi.org/10.1016/j.cosust.2013.08.003, 2013.

Haklay, M. and Weber, P.: OpenStreetMap: usergenerated street maps, IEEE Pervas. Comput., 7, 12-18, https://doi.org/10.1109/MPRV.2008.80, 2008.

Hanasaki, N., Kanae, S., Oki, T., Masuda, K., Motoya, K., Shirakawa, N., Shen, Y., and Tanaka, K.: An integrated model for the assessment of global water resources - Part 1: Model description and input meteorological forcing, Hydrol. Earth Syst. Sci., 12, 1007-1025, https://doi.org/10.5194/hess-12-1007-2008, 2008.

Hanasaki, N., Inuzuka, T., Kanae, S., and Oki, T.: An estimation of global virtual water flow and sources of water withdrawal for major crops and livestock products using a global hydrological model, J. Hydrol., 384, 232-244, https://doi.org/10.1016/j.jhydrol.2009.09.028, 2010.
Harvey, D.: Between space and time: reflections on the geographical imagination, Ann. Assoc. Am. Geogr., 80, 418-434, https://doi.org/10.1111/j.1467-8306.1990.tb00305.x, 1990.

Hasegawa, T., Fujimori, S., Ito, A., Takahashi, K., and Masui, T.: Global land-use allocation model linked to an integrated assessment model, Sci. Total Environ., 580, 787-796, https://doi.org/10.1016/j.scitotenv.2016.12.025, 2017.

Hejazi, M. I., Voisin, N., Liu, L., Bramer, L. M., Fortin, D. C., Hathaway, J. E., Huang, M., Kyle, P., Leung, L. R., Li, H.-Y., Liu, Y., Patel, P. L., Pulsipher, T. C., Rice, J. S., Tesfa, T. K., Vernon, C. R., and Zhou, Y.: 21st century United States emissions mitigation could increase water stress more than the climate change it is mitigating, P. Natl. Acad. Sci. USA, 112, 1063510640, https://doi.org/10.1073/pnas.1421675112, 2015.

Helbing, D.: Globally networked risks and how to respond, Nature, 497, 51-59, https://doi.org/10.1038/nature12047, 2013.

Hertel, T.: Global Trade Analysis: Modeling and Applications, Cambridge University Press, Cambridge, UK, https:// www.gtap.agecon.purdue.edu/products/gtap_book.asp (last access: 30 March 2017), 1997.

Hertel, T., Hummels, D., Ivanic, M., and Keeney, R.: How confident can we be of CGE-based assessments of Free Trade Agreements?, Econ. Model., 24, 611-635, https://doi.org/10.1016/j.econmod.2006.12.002, 2007.

Hoekstra, A. Y. and Chapagain, A. K.: Water footprints of nations: water use by people as a function of their consumption pattern, Water Resour. Manag., 21, 35-48, https://doi.org/10.1007/s11269-006-9039-x, 2006.

Hoekstra, A. Y. and Mekonnen, M. M.: The water footprint of humanity, P. Natl. Acad. Sci. USA, 109, 3232-3237, https://doi.org/10.1073/pnas.1109936109, 2012.

Hoff, H., Falkenmark, M., Gerten, D., Gordon, L., Karlberg, L., and Rockström, J.: Greening the global water system, J. Hydrol., Special Issue: Green-Blue Water Initiative (GBI), 384, 177-186, https://doi.org/10.1016/j.jhydrol.2009.06.026, 2010.

Hoff, H., Döll, P., Fader, M., Gerten, D., Hauser, S., and Siebert, S.: Water footprints of cities - indicators for sustainable consumption and production, Hydrol. Earth Syst. Sci., 18, 213-226, https://doi.org/10.5194/hess-18-213-2014, 2014.

Ibisch, P. L., Hoffmann, M. T., Kreft, S., Pe'er, G., Kati, V., Biber-Freudenberger, L., DellaSala, D. A., Vale, M. M., Hobson, P. R., and Selva, N.: A global map of roadless areas and their conservation status, Science, 354, 1423-1427, https://doi.org/10.1126/science.aaf7166, 2016.

IFPRI: Global Food Policy Report, International Food Policy Research Institute, Washington, DC, USA, https://doi.org/10.2499/9780896292529, 2017.

Janic, M.: Modelling the full costs of an intermodal and road freight transport network, Transp. Res. Part Transp. Environ., 12, 33-44, https://doi.org/10.1016/j.trd.2006.10.004, 2007.

Kaluza, P., Kölzsch, A., Gastner, M. T., and Blasius, B.: The complex network of global cargo ship movements, J. R. Soc. Interface, 7, 1093-1103, https://doi.org/10.1098/rsif.2009.0495, 2010.

Kandasamy, J., Sounthararajah, D., Sivabalan, P., Chanan, A., Vigneswaran, S., and Sivapalan, M.: Socio-hydrologic drivers of the pendulum swing between agricultural development and environmental health: a case study from Murrumbidgee River 
basin, Australia, Hydrol. Earth Syst. Sci., 18, 1027-1041, https://doi.org/10.5194/hess-18-1027-2014, 2014.

Karpiarz, M., Fronczak, P., and Fronczak, A.: International Trade Network: fractal properties and globalization puzzle, Phys. Rev. Lett., 113, 248701, https://doi.org/10.1103/PhysRevLett.113.248701, 2014.

Khanna, P.: Connectography: Mapping the Global Network Revolution, Hachette Publishers, London, UK, https://www. paragkhanna.com/connectography/ (last access: 30 March 2017), 2016.

Klein Goldewijk, K., Beusen, A., van Drecht, G., and de Vos, M.: The HYDE 3.1 spatially explicit database of humaninduced global land-use change over the past 12,000 years, Glob. Ecol. Biogeogr., 20, 73-86, https://doi.org/10.1111/j.14668238.2010.00587.x, 2011.

Knox, P. L. and McCarthy, L.: Urbanization: an introduction to urban geography, Pearson, Boston, MA, https://www.pearson.com/us/higher-education/program/KnoxUrbanization-An-Introduction-to-Urban-Geography- 3rdEdition/PGM213191.html?tab=overview (last access: 30 March 2017), 2012.

Konak, A., Coit, D. W., and Smith, A. E.: Multi-objective optimization using genetic algorithms: a tutorial, Special Issue - Genetic Algorithms and Reliability, Reliab. Eng. Syst. Safe., 91, 9921007, https://doi.org/10.1016/j.ress.2005.11.018, 2006.

Konar, M., Dalin, C., Suweis, S., Hanasaki, N., Rinaldo, A., and Rodriguez-Iturbe, I.: Water for food: the global virtual water trade network, Water Resour. Res., 47, W05520, https://doi.org/10.1029/2010WR010307, 2011.

Konar, M., Hussein, Z., Hanasaki, N., Mauzerall, D. L., and Rodriguez-Iturbe, I.: Virtual water trade flows and savings under climate change, Hydrol. Earth Syst. Sci., 17, 3219-3234, https://doi.org/10.5194/hess-17-3219-2013, 2013.

Konar, M., Evans, T. P., Levy, M., Scott, C. A., Troy, T. J., Vörösmarty, C. J., and Sivapalan, M.: Water resources sustainability in a globalizing world: who uses the water?, Hydrol. Process., 30, 3330-3336, https://doi.org/10.1002/hyp.10843, 2016a.

Konar, M., Reimer, J. J., Hussein, Z., and Hanasaki, N.: The water footprint of staple crop trade under climate and policy scenarios, Environ. Res. Lett., 11, 035006, https://doi.org/10.1088/17489326/11/3/035006, 2016b.

Kraucunas, I., Clarke, L., Dirks, J., Hathaway, J., Hejazi, M., Hibbard, K., Huang, M., Jin, C., Kintner-Meyer, M., van Dam, K. K., Leung, R., Li, H.-Y., Moss, R., Peterson, M., Rice, J., Scott, M., Thomson, A., Voisin, N., and West, T.: Investigating the nexus of climate, energy, water, and land at decisionrelevant scales: the Platform for Regional Integrated Modeling and Analysis (PRIMA), Climatic Change, 129, 573-588, https://doi.org/10.1007/s10584-014-1064-9, 2015.

Lach, D., Rayner, S., and Ingram, H.: Taming the waters: strategies to domesticate the wicked problems of water resource management, Int. J. Water, 3, 1-17, https://doi.org/10.1504/IJW.2005.007156, 2005.

Lambin, E. F. and Geist, H. J.: Land-Use and Land-Cover Change: Local Processes and Global Impacts, Springer Science \& Business Media, Heidelberg, Germany, https://doi.org/10.1007/3540-32202-7, 2008.

Lambin, E. F. and Meyfroidt, P.: Global land use change, economic globalization, and the looming land scarcity, P. Natl. Acad. Sci. USA, 108, 3465-3472, https://doi.org/10.1073/pnas.1100480108, 2011.

Laurance, W. F., Peletier-Jellema, A., Geenen, B., Koster, H., Verweij, P., Van Dijck, P., Lovejoy, T. E., Schleicher, J., and Van Kuijk, M.: Reducing the global environmental impacts of rapid infrastructure expansion, Curr. Biol., 25, R259-R262, https://doi.org/10.1016/j.cub.2015.02.050, 2015.

Liebowitz, S. J. and Margolis, S. E.: Path dependence, lock-in, and history, J. Law Econ. Organ., 11, 205-226, https://doi.org/10.2139/ssrn.1706450, 1995.

Limão, N. and Venables, A. J.: Infrastructure, geographical disadvantage, transport costs, and trade, World Bank Econ. Rev., 15, 451-479, https://doi.org/10.1093/wber/15.3.451, 2001.

Liu, D., Tian, F., Lin, M., and Sivapalan, M.: A conceptual sociohydrological model of the co-evolution of humans and water: case study of the Tarim River basin, western China, Hydrol. Earth Syst. Sci., 19, 1035-1054, https://doi.org/10.5194/hess-19-10352015, 2015.

Liu, J. and Savenije, H. H. G.: Food consumption patterns and their effect on water requirement in China, Hydrol. Earth Syst. Sci., 12, 887-898, https://doi.org/10.5194/hess-12-887-2008, 2008.

Liu, J., Mooney, H., Hull, V., Davis, S. J., Gaskell, J., Hertel, T., Lubchenco, J., Seto, K. C., Gleick, P., Kremen, C., and Li, S.: Systems integration for global sustainability, Science, 347, 1258832, https://doi.org/10.1126/science.1258832, 2015.

Liu, Y., Tian, F., Hu, H., and Sivapalan, M.: Socio-hydrologic perspectives of the co-evolution of humans and water in the Tarim River basin, Western China: the Taiji-Tire model, Hydrol. Earth Syst. Sci., 18, 1289-1303, https://doi.org/10.5194/hess-18-12892014, 2014.

Lotze-Campen, H., Müller, C., Bondeau, A., Rost, S., Popp, A., and Lucht, W.: Global food demand, productivity growth, and the scarcity of land and water resources: a spatially explicit mathematical programming approach, Agr. Econ., 39, 325-338, https://doi.org/10.1111/j.1574-0862.2008.00336.x, 2008.

Lu, Y., Nakicenovic, N., Visbeck, M., and Stevance, A.-S.: Policy: five priorities for the UN sustainable development goals, Nature News, 520, 432, https://doi.org/10.1038/520432a, 2015.

Marchand, P., Carr, J. A., Dell'Angelo, J., Fader, M., Gephart, J. A., Kummu, M., Magliocca, N. R., Porkka, M., Puma, M. J., Ratajczak, Z., Rulli, M. C., Seekell, D. A., Suweis, S., Tavoni, A., and D'Odorico, P.: Reserves and trade jointly determine exposure to food supply shocks, Environ. Res. Lett., 11, 095009 , https://doi.org/10.1088/1748-9326/11/9/095009, 2016.

Meyfroidt, P., Lambin, E. F., Erb, K.-H., and Hertel, T. W.: Globalization of land use: distant drivers of land change and geographic displacement of land use, Special Issue: Human settlements and industrial systems, Curr. Opin. Env. Sust., 5, 438-444, https://doi.org/10.1016/j.cosust.2013.04.003, 2013.

Montanari, A., Young, G., Savenije, H. H. G., Hughes, D., Wagener, T., Ren, L. L., Koutsoyiannis, D., Cudennec, C., Toth, E., Grimaldi, S., Blöschl, G., Sivapalan, M., Beven, K., Gupta, H., Hipsey, M., Schaefli, B., Arheimer, B., Boegh, E., Schymanski, S. J., Baldassarre, G. D., Yu, B., Hubert, P., Huang, Y., Schumann, A., Post, D. A., Srinivasan, V., Harman, C., Thompson, S., Rogger, M., Viglione, A., McMillan, H., Characklis, G., Pang, Z., and Belyaev, V.: "Panta Rhei - Everything Flows": change in hydrology and society - the IAHS Sci- 
entific Decade 2013-2022, Hydrol. Sci. J., 58, 1256-1275, https://doi.org/10.1080/02626667.2013.809088, 2013.

Müller, B., Bohn, F., Dreßler, G., Groeneveld, J., Klassert, C., Martin, R., Schlüter, M., Schulze, J., Weise, H., and Schwarz, N.: Describing human decisions in agent-based models - ODD + D, an extension of the ODD protocol, Environ. Modell. Softw., 48, 37-48, https://doi.org/10.1016/j.envsoft.2013.06.003, 2013.

Nelson, G. C., Valin, H., Sands, R. D., Havlík, P., Ahammad, H., Deryng, D., Elliott, J., Fujimori, S., Hasegawa, T., Heyhoe, E., Kyle, P., Lampe, M. V., Lotze-Campen, H., d'Croz, D. M., van Meijl, H., van der Mensbrugghe, D., Müller, C., Popp, A., Robertson, R., Robinson, S., Schmid, E., Schmitz, C., Tabeau, A., and Willenbockel, D.: Climate change effects on agriculture: economic responses to biophysical shocks, P. Natl. Acad. Sci. USA, 111, 3274-3279, https://doi.org/10.1073/pnas.1222465110, 2014.

O’Neill, B. C., Kriegler, E., Ebi, K. L., Kemp-Benedict, E., Riahi, K., Rothman, D. S., van Ruijven, B. J., van Vuuren, D. P., Birkmann, J., Kok, K., Levy, M., and Solecki, W.: The roads ahead: narratives for shared socioeconomic pathways describing world futures in the 21st century, Global Environ. Chang., 42, 169-180, https://doi.org/10.1016/j.gloenvcha.2015.01.004, 2015.

Pande, S. and Sivapalan, M.: Progress in socio-hydrology: a metaanalysis of challenges and opportunities, WIRES Water, e1193, https://doi.org/10.1002/wat2.1193, 2016.

Rees, W. and Wackernagel, M.: Urban ecological footprints: why cities cannot be sustainable - and why they are a key to sustainability, in: Urban Ecology, Springer, New York, USA, 537-555, https://doi.org/10.1007/978-0-387-73412-5, 2008.

Rockström, J., Gaffney, O., Rogelj, J., Meinshausen, M., Nakicenovic, N., and Schellnhuber, H. J.: A roadmap for rapid decarbonization, Science, 355, 1269-1271, https://doi.org/10.1126/science.aah3443, 2017.

Romero-Lankao, P., McPhearson, T., and Davidson, D. J.: The foodenergy-water nexus and urban complexity, Nat. Clim. Change, 7, 233-235, https://doi.org/10.1038/nclimate3260, 2017.

Sartori, M. and Schiavo, S.: Connected we stand: a network perspective on trade and global food security, Food Policy, 57, 114127, https://doi.org/10.1016/j.foodpol.2015.10.004, 2015.

Seto, K. C. and Reenberg, A.: Rethinking global land use in an urban era, in: Rethinking Global Land Use in an Urban Era, edited by: Seto, K. C. and Reenberg, A., The MIT Press, Cambridge, Massachusetts, USA, 1-7, https://doi.org/10.7551/mitpress/9780262026901.001.0001, 2014.

Shiklomanov, I. A.: Appraisal and assessment of world water resources, Water Int., 25, 11-32, https://doi.org/10.1080/02508060008686794, 2000.

Sivapalan, M. and Blöschl, G.: Time scale interactions and the coevolution of humans and water, Water Resour. Res., 51, 69887022, https://doi.org/10.1002/2015WR017896, 2015.

Sivapalan, M., Savenije, H. H. G., and Blöschl, G.: Sociohydrology: a new science of people and water, Hydrol. Process., 26, 1270-1276, https://doi.org/10.1002/hyp.8426, 2012.

Sophocleous, M.: Retracted: conserving and extending the useful life of the largest aquifer in North America: the future of the High Plains/Ogallala Aquifer, Groundwater, 50, 831-839, https://doi.org/10.1111/j.1745-6584.2012.00965.x, 2012.
Srinivasan, V., Sanderson, M., Garcia, M., Konar, M. Blöschl, G., and Sivapalan, M.: Prediction in a sociohydrological world, Hydrol. Sci. J., 62, 338-345, https://doi.org/10.1080/02626667.2016.1253844, 2017.

Steffen, W., Richardson, K., Rockström, J., Cornell, S. E., Fetzer, I., Bennett, E. M., Biggs, R., Carpenter, S. R., de Vries, W., de Wit, C. A., Folke, C., Gerten, D., Heinke, J., Mace, G. M., Persson, L. M., Ramanathan, V., Reyers, B., and Sörlin, S.: Planetary boundaries: guiding human development on a changing planet, Science, 347, 1259855, https://doi.org/10.1126/science.1259855, 2015.

Stehfest, E.: Diet: food choices for health and planet, Nature, 515, 501-502, https://doi.org/10.1038/nature13943, 2014.

Stehfest, E. and Bouwman, L.: $\mathrm{N}_{2} \mathrm{O}$ and $\mathrm{NO}$ emission from agricultural fields and soils under natural vegetation: summarizing available measurement data and modeling of global annual emissions, Nutr. Cycl. Agroecosys., 74, 207-228, https://doi.org/10.1007/s10705-006-9000-7, 2006.

Stehfest, E., van den Berg, M., Woltjer, G., Msangi, S., and Westhoek, H.: Options to reduce the environmental effects of livestock production - comparison of two economic models, Agr. Syst., 114, 38-53, https://doi.org/10.1016/j.agsy.2012.07.002, 2013.

Stehfest, E., van Vuuren, D., Kram, T., Bouwman, L., Alkemade, R., Bakkenes, M., Biemans, H., Bouwman, A., den Elzen, M., Janse, J., Lucas, P., van Minnen, J., Muller, M., and Gerdien Prins, A.: Integrated Assessment of Global Environmental Change With IMAGE 3.0 Model Description and Policy Applications, Netherlands Environmental Assessment Agency, De Bilt, the Netherlands, http://www.pbl.nl/en/publications/integrated-assessmentof-global-environmental-change-with- IMAGE-3.0 (last access: 30 March 2017), 2014.

Troy, T. J., Konar, M., Srinivasan, V., and Thompson, S.: Moving sociohydrology forward: a synthesis across studies, Hydrol. Earth Syst. Sci., 19, 3667-3679, https://doi.org/10.5194/hess-19-36672015, 2015.

UN Population Division: World Population Prospects: the 2015 Revision, United Nations, Department of Economic and Social Affairs, Population Division, New York, USA, http://www.un.org/en/development/desa/publications/ world-population-prospects-2015-revision.html (last access: 30 March 2017), 2015.

United Nations: World Urbanization Prospects, United Nations, Department of Economic and Social Affairs, Population Division, New York, USA, https://esa.un.org/unpd/wup/ (last access: 30 March 2017), 2012.

United Nations: Transforming Our World: the 2030 Agenda for Sustainable Development, New York, USA, http://www.un.org/ ga/search/view_doc.asp?symbol=A/RES/70/1\&Lang=E (last access: 30 March 2017), 2015.

United Nations Environmental Programme: City-level Decoupling: Urban Resource Flows and the Governance of Infrastructure Transitions. A Report of the Working Group on Cities of the International Resource Panel, New York, USA, https://www.wrforum.org/uneppublicationspdf/citylevel-decoupling-urban-resource-flows-and-the-governance -of-infrastructure-transitions/ (last access: 30 March 2017), 2013. 
United Nations Water: Annual Report, United Nations, New York, USA, http://www.unwater.org/publications/ un-water-annual-report-2015/ (last access: 30 March 2017), 2015.

van Emmerik, T. H. M., Li, Z., Sivapalan, M., Pande, S., Kandasamy, J., Savenije, H. H. G., Chanan, A., and Vigneswaran, S.: Socio-hydrologic modeling to understand and mediate the competition for water between agriculture development and environmental health: Murrumbidgee River basin, Australia, Hydrol. Earth Syst. Sci., 18, 4239-4259, https://doi.org/10.5194/hess-184239-2014, 2014.

van Vuuren, D. P., Lucas, P. L., Häyhä, T., Cornell, S. E., and Stafford-Smith, M.: Horses for courses: analytical tools to explore planetary boundaries, Earth Syst. Dynam., 7, 267-279, https://doi.org/10.5194/esd-7-267-2016, 2016.

Verburg, P. H. and Overmars, K. P.: Combining top-down and bottom-up dynamics in land use modeling: exploring the future of abandoned farmlands in Europe with the Dyna-CLUE model, Landsc. Ecol., 24, 1167, https://doi.org/10.1007/s10980009-9355-7, 2009.

Verburg, P. H., Dearing, J. A., Dyke, J. G., van der Leeuw, S., Seitzinger, S., Steffen, W., and Syvitski, J.: Methods and approaches to modelling the Anthropocene, Global Environ. Chang., 39, 328-340, https://doi.org/10.1016/j.gloenvcha.2015.08.007, 2016.

Verstegen, J. A., Hilst, F., Woltjer, G., Karssenberg, D., Jong, S. M., and Faaij, A. P.: What can and can not we say about indirect land-use change in Brazil using an integrated economic-land-use change model?, GCB Bioenergy, 8, 561-578, https://doi.org/10.1111/gcbb.12270, 2016.

von Lampe, M., Willenbockel, D., Ahammad, H., Blanc, E., Cai, Y., Calvin, K., Fujimori, S., Hasegawa, T., Havlik, P., Heyhoe, E., Kyle, P., Lotze-Campen, H., Mason d'Croz, D., Nelson, G. C., Sands, R. D., Schmitz, C., Tabeau, A., Valin, H., van der Mensbrugghe, D., and van Meijl, H.: Why do global long-term scenarios for agriculture differ? An overview of the AgMIP Global Economic Model Intercomparison, Agr. Econ., 45, 3-20, https://doi.org/10.1111/agec.12086, 2014.

Vrugt, J. A., Gupta, H. V., Bastidas, L. A., Bouten, W., and Sorooshian, S.: Effective and efficient algorithm for multiobjective optimization of hydrologic models, Water Resour. Res., 39, WRCR9547, https://doi.org/10.1029/2002WR001746, 2003.
Wada, Y. and Bierkens, M. F. P.: Sustainability of global water use: past reconstruction and future projections, Environ. Res. Lett., 9, 104003, https://doi.org/10.1088/1748-9326/9/10/104003, 2014.

Wada, Y., van Beek, L. P. H., van Kempen, C. M., Reckman, J. W. T. M., Vasak, S., and Bierkens, M. F. P.: Global depletion of groundwater resources, Geophys. Res. Lett., 37, GRL27382, https://doi.org/10.1029/2010GL044571, 2010.

Wada, Y., van Beek, L. P. H., and Bierkens, M. F. P.: Nonsustainable groundwater sustaining irrigation: a global assessment, Water Resour. Res., 48, W00L06, https://doi.org/10.1029/2011WR010562, 2012.

Wagener, T., Sivapalan, M., Troch, P. A., McGlynn, B. L., Harman, C. J., Gupta, H. V., Kumar, P., Rao, P. S. C., Basu, N. B., and Wilson, J. S.: The future of hydrology: an evolving science for a changing world, Water Resour. Res., 46, W05301, https://doi.org/10.1029/2009WR008906, 2010.

Walker, R., Arima, E., Messina, J., Soares-Filho, B., Perz, S., Vergara, D., Sales, M., Pereira, R., and Castro, W.: Modeling spatial decisions with graph theory: logging roads and forest fragmentation in the Brazilian Amazon, Ecol. Appl., 23, 239-254, https://doi.org/10.1890/11-1800.1, 2013.

Wise, M., Calvin, K., Thomson, A., Clarke, L., Bond-Lamberty, B., Sands, R., Smith, S. J., Janetos, A., and Edmonds, J.: Implications of limiting $\mathrm{CO}_{2}$ concentrations for land use and energy, Science, 324, 1183-1186, https://doi.org/10.1126/science.1168475, 2009.

Woltjer, G. B., Kuiper, M., Kavallari, A., van Meijl, H., Powell, J. P., Rutten, M. M., Shutes, L. J., and Tabeau, A. A.: The MAGNET Model: Module Description, LEI Wageningen UR, https://www.wur.nl/en/Publication-details.htm?publicationId= publication-way-343535383037 (last access: 30 March 2017), 2014.

Young, O. R., Berkhout, F., Gallopin, G. C., Janssen, M. A., Ostrom, E., and Van Der Leeuw, S.: The globalization of socio-ecological systems: an agenda for scientific research, Global Environ. Chang., 16, 304-316, https://doi.org/10.1016/j.gloenvcha.2006.03.004, 2006.

Zhang, Y.: Urban metabolism: a review of research methodologies, Environ. Pollut., 178, 463-473, https://doi.org/10.1016/j.envpol.2013.03.052, 2013. 